\title{
Introduction: Current Perspectives on Islamic Family Law in Africa
}

\author{
Fulera Issaka-Toure \\ Islamic Studies Department, University of Bayreuth, Bayreuth, Germany \\ Department for the Study of Religions, University of Ghana, Legon, Ghana \\ fissaka-toure@ug.edu.gh
}

Ousseina D. Alidou

Department of African, Middle Eastern and South Asian Languages and Literatures, Rutgers University, New Brunswick, New Jersey, United States oalidou@scarletmail.rutgers.edu

\begin{abstract}
This special issue of Islamic Africa brings together new critical perspectives on the status of Islamic Family Law, commonly referred to as sharía, within four African countries - Ghana, Kenya, Mozambique and Senegal - each reflecting distinctive gendered cultural, colonial and postcolonial realities. The introduction provides a general overview of the state of the art on Islamic family law in Africa and highlights the significant thematic focus of each contribution and the new areas for further inquiry that the volume opens. These topics and questions include among others: (a) the ways in which European colonialism and contemporary democratization processes have opened spaces for religious pluralism, thereby shaping the articulation of Muslim personal law within different African postcolonial state judicial systems; (b) how Islamic judicial practices, institutions, and authorities such as malamai and/ or Kadhis engage themselves with the secular state and/or are constrained by both the state and by the legal pluralism encountered within both Muslim majority and minority African countries; (c) the gendered implications of the hierarchical relation between Kadhi Courts and a national High Court; (d) the benefits and/or shortcomings of harmonizing Islamic Family Law; (e) what is to be learnt from women choosing to settle marital disputes and divorce within and/or outside the "legal protective space" afforded by the state judicial system and its inclusion of Islamic Family Law; (f) the role of human agency in influencing the administration of Islamic family law and/or interpreting the law; how judicial systems that are shaped by European and
\end{abstract}


Islamic patriarchal systems confronted by the resilience of indigenous matrilineal Customary Law within contemporary African societies; and (g) the compatibility between the various articulation of African Islamic family laws with universal human rights and individual freedom. Ultimately, this special issue of Islamic Africa offers an insightful reflection on how Islamic Family Law plays an important role in democratic constitution-making or testing processes.

\section{Keywords}

Africa - Shari`a - human agency - patriarchy - legal pluralism - gendered citizenship

Broadly speaking, Islamic family law can be considered one part of sharīa, or Islamic law. This explains why it is sometimes identified with sharīa more generally. ${ }^{1}$ This identification is not incorrect, considering that the available historical materials refer to it as sharīa. ${ }^{2}$ Writing within the context of the reformation and transformation of Islamic family law in Africa, An-Na'im made the following arguments in favour of "the need to transform the basis of family law":

First, the notion of an immutable body of principles of Shari'a as universally binding on all Muslims for eternity is simply not supported by the actual practice of Muslim societies and their states throughout history. Second, Shari'a has not had exclusive jurisdiction in the administration of justice throughout Islamic history, as the state always exercised secular jurisdiction, nor was Shari'a free from state supervision wherever the state permitted it to be enforced. Third, the ability of individual Muslims to seek and act upon independent fatwa [non-binding religious decree] has always been a valuable resource for addressing the personal religious needs of believers, even regarding what might technically be legal subject matter'. The institutionalization of this function does not exhaust the possibilities of independent legal advice, which believers can observe voluntarily without state enforcement or control. Fourth, recent Islam-

1 An-Naim, "Sharia and Islamic family law".

2 Shamil Jeppie, Ebrahim Moosa and Richard Roberts, "Introduction", in Muslim Family Law in Sub-Saharan Africa: Colonial Legacies and Post-Colonial Challenges, ed. S. Jeppie, E. Moosa, and R. Roberts, Amsterdam, Amsterdam University Press, 2010, p. 13-61, J.N.D Anderson, Islamic Law in Africa, New York, Routledge, 2008. 
ic law reforms and social developments that made the entire corpus of Shari'a available and accessible to all concerned also exposed the moral and political problems of selective enactment and enforcement of some of these norms over others. ${ }^{3}$

Three issues arise with regard to the above comments made by An-Naim on Islamic family law. These are, first, the operation of Islamic family law in a legally pluralistic culture; second, Muslims' liberty to consult with jurisconsults, or muftis, for non-binding religious decree; and third, coercive structures of the state. These three issues necessitate discussing Islamic family law as not one but many different laws. In other words, there is no Islamic family law but Islamic family laws, as not every situation of application has the same realities on the ground.

This forms the basis of this introduction to current perspectives on Islamic family law in Africa. It is important to highlight the application of Islamic family law and its relationship to legal pluralism, because in several states in contemporary Africa, Islamic family law is applied simultaneously with other legal systems, and each country has its own specific ways of applying laws, including different interpretations of what constitutes Islamic family law and different legal statuses accorded to it by law. Both historical and recent developments on the application of sharīa or Islamic family law gives credence to the position of legal pluralism in relation to its application. ${ }^{4}$

Sharīa in African countries prior to their independence had three categorisations with regard to its implementation: fundamental law, dominant law and particular law. Alongside the creation of nation-states, the sharía was also colonised as part of the colonising project. In British colonies (e.g. Ghana and Nigeria) the colonial legal system categorised sharīa in broad terms as "Muhammadan law." In some parts of the British colonies, some pre-existing

3 Abdullahi A. An-Naim, "Shari'a and Islamic Family Law: Transition and Transformation", in Islamic Family Law in a Changing World: A Global Resource Book, ed. A. A. An-Naim, 2002, p.1-22.

4 Ido Shahar, "Legal Pluralism and the Study of Shari'a Courts", Islamic Law and Society, 15/1 (2008), p.112-141. M. Christian Green, "Religious and Legal Pluralism in Recent African Constitutional Reform", Journal of Law and Religion, 28/2(2012-13), p. 401-439. Anne Hellum, "Human Rights andGender Relations in Postcolonial Africa: Options and Limits for the Subjects of Legal Pluralism", Law and Social Inquiry, 25/2 (200o), p. 635-655. R. S. Suttner, "Legal Pluralism in South Africa: A Reappraisal of Policy", The International and Comparative Law Quarterly, 19/1 (1970), p. 134-153. Paolo Sartori and Ido Shahar, "Legal Pluralism in MuslimMajority Colonies: Mapping the Terrain", Journal of the Economic and Social History of the Orient, 55/4/5 (2012), p. 637-663. 
aspects of sharī'a were left to prevail, especially concerning personal law, albeit with supervision from the broader legal system of the state in question. ${ }^{5}$

The colonisation of shari`a has given birth to postcolonial challenges in each nation-state, be it Muslim majority or minority. In Nigeria, the major postcolonial challenge is the reintroduction of criminal code in the domain of sharīa in the late 1990s. In the case of Kenya and Zanzibar for example, the Kadhi courts (see Hashim's paper in this volume) prevail over Muslim personal law relating to marriage, divorce and inheritance. In Kenya, they form part of the legal structure; the fact that the Kadhi courts operate within the Kenyan legal system means they are subject to state supervision and sometimes control. ${ }^{6}$

The establishment of modern states from the nineteenth century onwards witnessed a number of shifts in the ways and manner in which Islamic family law was applied in Muslim contexts. ${ }^{7}$ The status of Islamic family law in Africa is actually an evolution and continues to evolve. Countries such as those in the Maghreb or North Africa have modified their family laws to accommodate current ideas of women's rights and the nature of marriage. Such moves are in line with contemporary international standards dictated by international values of human rights. ${ }^{8}$

In particular, such evolution of Islamic family law in Africa has to do with different historical trajectories of each context. In this regard, although Islamic texts play a significant role in the production of Islamic family law, the role of human agents and historical contexts cannot be overlooked. This forms the basis of having multiple variations of Islamic family law in Africa, all purporting to be the sharîa. In short, different variations of Islamic family laws pertain in different countries, sometimes appearing in legal codes and sometimes not.

5 J.N.D Anderson, Islamic Law in Africa, Richard Roberts, Litigants and Households: African Disputes and Colonial Courts in the French Soudan, 1895-192, Heinemann, Portsmouth, 2005. Elke E. Stockreiter, Islamic Law, Gender, and Social Change in Post-Abolition Zanzibar, Cambridge, Cambridge University Press, 2015. Mervyn Hiskett, "Commisioner of Police v. Musa Kommanda and Aspects of the Working of the Gold Coast Marriage and Muhammedan Ordinance", Journal of African Law 20 (1976), p. 127-146.

6 Ousseina Alidou, and Hassana Alidou, "Women, Religion, and the Discourse of Legal Ideology in Niger Republic", Africa Today 54/3 (2008), p. 21-36; Shamil Jeppie, Ebrahim Moosa and Richard Roberts, eds., Muslim Family Law in Sub-Saharan Africa: Colonial Legacies and PostColonial Challenges, Amsterdam, Amsterdam University Press, 2010.

7 Ziba Mir-Hosseini, Marriage on Trial, a Study of Islamic Family Law: Iran and Morocco Compared, London and New York, I.B. Tauris, 2000.

8 Ann Elizabeth Mayer, "Reform of Personal Status Laws in North Africa: A Problem of Islamic or Mediterranean Laws?", Hafidha Chekir, "Women, the Law, and the Family in Tunisia”, Gender and Development, 4/2 (1996), p.43-46. 
However, in cases where there is no Islamic legal code, Islamic family law is still applied contextually.

In contemporary times there has arisen the need for the codification or reform of Islamic family laws both in Africa and elsewhere around the globe. This particular discussion has to do with pertinent issues of women's and children's rights that have arisen especially within the context of nation-states. Such debates have taken different turns within various settings, and Islamic methodologies such as ijtihād (independent legal reasoning) have become important in order to give such debate a credible Islamic outlook.

In fact, this has led to the codification of sharīa in some contexts which raised particular question on who owns the production of sharīa or whose or which is legitimate. In fact, it has been argued that it is legitimate to use ijtihād for reform, yet such debates have been largely politicised. ${ }^{9}$ By the same token intra-Muslim tensions in some countries have also led to calls to codify Islamic family law to address conflicts in interpretations of the shari'a between Islamic madhhabs/schools. Furthermore, Muslim citizens are also demanding that the state must not only recognize the Kadhis' court for example but must also secure its reform to respond to a constitutional regime of citizen's rights, especially women's rights.

The call for the codification of Islamic family law in Muslim minority countries - such as Kenya for example - raises important questions. This has to do first with the mechanism for consensus-building on the madhhab to adopt in a highly competitive and diversified Islamic religious landscapes. Second, there is an additional difficulty of racial differentiation within the Kenyan context of an African Muslim minority. ${ }^{10}$ Furthermore, the process also raises the

9 Nihan Altinbas, "Marriage and Divorce in the Late Ottoman Empire: Social Upheaval, Women's Rights, and the Need for New Family Law", Journal of Family History 39/2 (2004), p. 114-125, Ziba Mir-Hosseini, "How the Door of Ijtihad Was Opened and Closed: A Comparative Analysis of Recent Family Law Reforms in Iran and Morocco", Wash. \& Lee L. Review 1499 (2007), p. 1500-1511, Kristen Stilt, Salma Waheedi and Swathi Gandhavadi Griffin, "The Ambitions of Muslim Family Law Reform", Harvard Journal of Law \& Gender 41, p. 301-341, Rudolph Peters, "From Jurists' Law to Statute Law or What Happens when the Shari'a is Codified", in Shaping the Current Islamic Reformation, ed. Robert B. A and Barbara Allen, London, Frank Cass, 2003, p. 82-95, John L. Esposito with Natana J, Delong-Bas. Women in Muslim Family Law, Syracuse, Syracuse University Press, 2001.

10 Ousseina Alidou, "Muslim Women Leaders and Legal Reform in Postcolonial Kenya", 2016. Hawwa 14/1 (2016), p.53-77; Ousseina Alidou, "The Ma'had Tradition of Mwalim Azara Mudira: Creating a Woman's Space for Islamic Education in Kenya", in Ousseina Alidou, Muslim Women in Postcolonial Kenya: Leadership, Representation, and Social Change, Madison, University of Wisconsin Press, 2013, p. 82-104. Kevin Odimbe Wanyonyi, The Kadhis' Courts in Kenya: Towards Enhancing Access to Justice for Muslim Women, MA Thesis, Lund University, 2016. 
question of the role of the state in the codification process of Islamic family law and citizens' responses to this. While there is literature on codification projects in Muslim majority countries, this special issue offers a window into its manifestations in Muslim minority countries such as Kenya.

In this regard, the role of individual states becomes important in the production of Islamic family laws. On the one hand, the state becomes the central point of producing either a code or standards followed by the judiciary to implement Islamic family law in every context. In contexts where there are no formal Islamic legal codes, some particular standards have been laid down to be followed by the implementers of Islamic family law. In some of such instances, either Islamic family law is applied by Islamic religious leaders through the personal volition of Muslims' submission to them or, in some instances, the judicial setting allows for Kadhi courts to prevail with state supervision but without a legal code. ${ }^{11}$

Thus far, the literature raises three major issues concerning the current perspective on Islamic family law in Africa. These are gender and human rights issues, issues of legal pluralism and the role of the modern state. With regard to the first issue, gender and human rights, the crux of the criticism of Islamic family law is its lack of recognition of women's rights. As it stands, the argument is that women's rights are human rights issues which must not be ignored in the application of Islamic family law. Since the application is based on traditional Islamic jurisprudence and, in some cases, not reformed to meet modern standards of human rights, its application becomes problematic from a human rights standpoint. To meet the demands of human rights and gender, some countries have reformed their codes of Islamic family law.

The issue of legal pluralism has again been one of the characteristics the application of Islamic family law in Africa since some countries in Africa lump Islamic family law into a legal pluralistic culture along with "traditional" law.

11 For countries without Islamic legal codes see the following: On Tanzania see Robert V. Makaramba, "The Secular and the State of Islamic Law in Tanzania", in Muslim Family Law in Sub-Saharan Africa: Colonial Legacies and Post-Colonial Challenges, ed. S. Jeppie, E. Moosa, and R. Roberts, Amsterdam, Amsterdam University Press, 2010, p. 273-304, Salma Maoulidi, "Why Bring Islamic Law into the Public Space?", WLUML 27 (2005), p. 1-8, On Kenya see Osseina D. Alidou, Muslim Women in Postcolonial Kenya: Leadership, Representation and Social Change, Wisconsin, The University of Wisconsin Press, 2013. For more on countries with codes see for example on Mali Benjamin F. Soares, "The Attempt to Reform Family Law in Mali", Die Welt Des Islams 49/3-4 (2009), p.398-428, on Senegal see Lucy Creevey, "Islam, Women and the Role of the State in Senegal", Journal of Religion in Africa 26/3 (1996), p. 268-307. On Tunisia see Hafidha Chekir, "Women, the Law, and the Family in Tunisia", on Morocco see Zakia Salime, Between Feminism and Islam: Human Rights and Sharia Law in Morocco, Minneapolis, University of Minnesota Press, 2011. 
The issue of legal pluralism has different implications in relation to how different states produce and apply Islamic family law. Each state has its own history and decides how to go about applying Islamic family law. The state also has a large stake in the setting of its judiciary and how it has to function. In essence, legal pluralism and gender and human rights issues are interconnected with the state in the application of Islamic family law. Consequently, the state becomes a critical point of reference in current application of Islamic family law.

In this vein, the question we are asking here is: is there something called an Islamic family law in Africa? Surely, the answer is no, ${ }^{12}$ because different countries in Africa have different histories, different interpreters of Islam and different producers and implementers of Islamic family law. In this wise, it is apt to argue that there is Islamic family law in Africa but that it appears differently in various countries of the continent, and thus it would be more appropriate to speak of "Islamic family laws." This is particularly the question this issue seeks to answer in relation to the fact that the papers give various dimensions of Islamic family law in Africa. The four papers in this issue give different perspectives on the application of Islamic family law in different African countries ranging from Ghana, Kenya, Senegal and Mozambique. Liazzate Bonate's paper presents the idea of the application of Islamic family law which is applied in tandem with other laws such as traditional customary laws and state law. In essence, she argues that, Mozambican Muslims are subjects of different sources of law that come together to form their experiences of Islamic family law. Abdulkadir Hashim's paper indicates the jurisprudential difficulties in the application of Islamic family law in Kenya and proposes progressive comparative jurisprudential approach in responding to emerging legal issues facing Muslim litigants in the Kenyan courts. Issaka-Toure's paper presents the idea of the application of Islamic family law in Ghana in a context of legal pluralism and indicates the ways in which Islamic religious authorities collaborate with the state to apply Islamic family law. Annelien Bouland's paper is about the practice of divorce in relation to Islamic family law in Senegal. She argues that, although divorce outside of court is illegal according to the Senegalese family code, extra-legal divorce does happen outside in ways in which Islam and tradition intersect to shape the practices of divorce.

Why do so many Muslim litigants, especially Muslim women, resort to Islamic justice systems - Islamic association centers (Ghana), Kadhis' courts (Kenya), and informal arrangements involving kin and Islamic authorities (Mozambique and Senegal) - for mediation of marital issues or disputes? The

Shamil Jeppie, Ebrahim Moosa and Richard Roberts, eds., Muslim Family Law. 
article on Senegal draws our attention to other factors - the gendered implications of the cultural meanings of marriage and divorce in Senegalese society that influence Senegalese Muslim women's preference to settle divorce outside state courts despite the protection of women's rights under the modern family code applied in Senegal's court system.

This special issue of Islamic Africa highlights in a significant manner the manifestation of African Muslims' agency and their persistence in producing a malleability of both Islamic family laws and colonially inherited common laws in the adjudication of personal law within postcolonial nation-states regardless of whether Muslims are majority or minority citizens. Such malleability lies in the importance of the socio-cultural symbolic meanings of marriage, and divorce mediation in African Muslim societies and how such symbolic understandings affect the gendered pursuit of rights and justice in the context of marital disputes and dissolution.

In general, with varying nuances, the articles examine the mechanisms by which African Muslim polity engage the postcolonial state in their bargaining for the constitutional recognition of Islamic family law within the secular state's constitutional framework of equality of citizenship and right of culture and religious identity. The states' plural legal systems and Muslims themselves are located in a context in which the application of Islamic family law must be compatible with international conventions on human rights and women's rights adopted by most African modern secular states.

However, the articles also underscore the role of human agency in influencing the administration of Islamic family law and or interpreting the law. That is to say, the postcolonial state, jurisprudence system and the rights regime do not have total control in ensuring the primacy of state judicial culture in settling marital disputes and securing personal rights, because there are cases where Muslim women for example opt for out of court settlements (Senegal) or where Muslim citizens fight for the state to support Islamic personal law in matters related to rights rather than accept the common law rights approach.

Hence, the special issue brings to the fore the manner in which Islamic law is actualised in tandem with other systems of law in contemporary modern nation states. While Islamic law has long operated within and alongside different legal systems, for example, with the emir or caliph having powers to issue orders or rulings, these articles demonstrate particularities of contemporary modern nation states. The secular interferes in the divine, and vice versa. These papers illustrate some of the many forms of legal and jurisprudential cultures within which Islamic family law operate. Each of these cultures renders certain aspects of application of Islamic family law illegal. 
Additionally, the diversity of cultural norms in African Muslim societies, including kinship structures (matrilineal vs. patrilineal), and gender norms, cultural ways of interpreting Islam and assumptions about gendered citizens, contributes to how Muslims engender postcolonial legal innovations regarding Islamic family laws and mediation frameworks as applied to marriage contracts, inheritance and dissolution. In some cases, like Ghana (see Issaka-Toure's paper), Islamic family law is a by-product of Muslim judicial culture-symbiotic relationship with state jurisprudence.

In Kenya, however, there remains tension between Muslims and the state regarding the status of Kadhi courts within the judicial hierarchy, alongside intra-Muslim and intra-judiciary tensions. In Senegal, mediation outside the radar of state jurisprudence seems preferred, whereas in Mozambique, Muslims' belongingness to three different legal systems - an Islamic family law system, the state and a traditional system - is highlighted. In particular, the gendered rights and differentiations Muslim women either suffer or benefit from is emphasised.

Given the democratization processes African countries are undergoing, African Muslims are contributing to legal innovations by contributing to the debates on gender, cultural and religious rights, and Islamic family law making, right granting and justice achievement to accommodate diversity and national pluralism. This is in contrast to the colonial subordination of customary laws and religious family laws to colonial legal frameworks. This trend is particularly significant because it is one of the strengths of this special issue of Islamic Africa. Together, the papers demonstrate the diverse ways in which such issues are handled both by individual nation-states as well as by Muslim citizens. At this point it is significant to ask a specific question about the successes of "regendering"13 in Africa, particularly with regard to the application of Muslim family laws in Africa. With regard to this special issue the idea has to be rethought concerning the reception of the Family Code (Senegal), community courts (Mozambique), marital conflicts and resolutions (Ghana) and Kadhi court (Kenya).

A close reading of the articles submitted invites us to think of the debates on Islamic family laws and their compatibility with universal human rights and individual freedom and the tensions for the proponents of personal laws. Both positions are reflected in the articles submitted with degrees of nuances. On the one hand, globalization and the twentieth century's technological

13 Mindie Lazarus-Black, Everyday Harm: Domestic Violence, Courts Rites and Cultures of Reconciliation, Urbana, University of Illinois Press, 2007. 
revolution have projected the concepts of fundamental human rights and freedom to even the most culturally traditional societies.

As a result, countries with personal law systems experience a clash between two ideological perspectives. Opponents of religiously based separate systems embrace a concept of universal human rights where there is an urgent need for establishing globally shared legal frameworks on cross-cultural foundations. Those who favour maintaining personal law are suspicious of such (primarily Western-based) concepts as human rights and individualism and challenge their compatibility with valued cultural traditions. ${ }^{14}$

Indeed, as Makau Mutua's essay "Is the age of Human rights over?" argues, the paradigm of human rights referred to as "modern" is in fact "Euro-Christiancentric" yet is raised to a level of universalism. ${ }^{15}$ Mutua particularly raises the question of the universality of human rights discourse as the guarantor of truth without which there is no human civilisation. This piece interrogates the deficits and normative gaps of the human rights regime and concludes that the golden age of human rights is over. In this regard, the application of Islamic family laws in various contexts on the continent raises issues concerning cultural relativism and universalism of human rights, a tension vividly explored in this special issue.

14 Bassam Tibi, "Islamic Law/Shari'a, Human Rights, Universal Morality and International Relations", Human Rights Quarterly 16 (1994) 277-99, Jayanth K. Krishnan and Marc Galanter, "Personal Law and Human Rights in India and Israel", Maurer School of Law Indiana University paper 419. $2000 \mathrm{http}: / /$ www.repository.law.indiana.edu/facpub.

15 Makau Mutua, "Is the Age of Human Rights Over?" in Routledge Companion to Literature and Human Rights, ed. Sophia A. McClennen and Alexandra Schultheis Moore, London and New York, Routledge, 2016, p. 450-458. 